\title{
Simulation Game, a Strategy for Achieving Technology Education in Nigerian Secondary Schools
}

\author{
Dr. Ann E. Umeh \\ Department of Science Education \\ Federal University of Technology, Minna
}

\begin{abstract}
Simulation game is a concentrated learning exercise specifically designed to represent important real-life activities by providing the learner(s) with the essence or essential elements of the real situation without its hazards, lost or time constraints. Games are contests based on skill and or chance that are played according to rules. The study investigated the effects of simulation game as a strategy for achieving technology education in the Nigerian Secondary Schools. It was an experimental study and use a pre-test treatment control, post-test design. The experimental group was taught Technology instruction with simulation game. Two research questions and two well hypotheses guided the study. One researcher made instrument of 20 item multiple choice questions was used for both pre-test and post-tests. Data collected were analyzed using both mean scores and t-tests. Results showed that gender had no significant effect on the use of simulation game as shown by the performance of the boys and girls. However, the use of simulation game strategy enhances the teaching and learning of Technology Education in the Nigerian Secondary Schools.
\end{abstract}

\section{INTRODUCTION}

Simulation and game are actually a method of learning which has been around a long time. Simulation and game are frequently cast in the form of competitive to add motivation and interest (Abret 2008)

According to Boocock (2000), simulation and game for older students and adults have been seriously investigated, through there is one marked exception in the area of skills and tactical training. He went further to say that, during and since World War II, extensive use of simulation and game has been made of psychomotor skills training with stimulators in such areas as aircraft training, driver education and weapons systems operation. Effective use of simulation and game has been made of war games tactical training. On the other hand, simulation in such areas as the social studies, teacher education and management decisionmaking are largely a product of the 1960s and early 1970s (Raymound 2010).

Emphasis on the essential elements of learning situations accordingly suggests that simulation and game should count some elements of the real-life situation. The elements omitted of course, are unimportant to the specific purpose of the simulation or game; leaving them out, in fact simply avoids unnecessary complexities or confusion which might otherwise occur (Robert 2010).

According to Wilson (2009), simulation and gaining have at least three ancestors, simulator trainers, games and role-playing. Simulator trainers, some-times called mock-ups.

Simulation and games like other well-organized learning experiments must have been derived from a carefully designed around clearly specified objectives. The must objectives must have 
been derived from a careful analysis of what is to be learned and a determination that a simulation exercise is particularly appropriate as a method of providing the needed learning experience (Ore 2000).

Simulation design consist of a systematic analysis of the problem, process, or situation to be taught, the selection of a suitable model (format) for the game, setting up the parts or roles to be played in the simulating the model, establishing necessary rules for operating the game so it will function effectively toward the specified objectives according Jummy (2014), using stimulation game for learning in schools can increase the students internal motivation and learning achievement. He went further to say that simulation game have been recognized as being a good tool to promote learners to actively participate in learning activities,

Brown (2012), revealed that simulation game which aimed at improving student, learning among gender have better learning achievement when demonstrated effectively, he went further to say that the learning motivation and achievement of students can be increased and their competencies and knowledge can be promoted.

\section{Research Questions}

Two research questions guided this study and they are;

1. How can simulation game enhance teaching and learning of technology education in the Nigerian secondary schools?

2. How can simulation game enhance teaching of technology education of male and female in the Nigerian secondary schools?

\section{Research Hypotheses}

Two null hypotheses were formulated to answer the research questions,

HO1: there is no significant difference on the academic performance of student taught technology education using simulation game in the teaching and learning process.

HO2: there is no significant difference in the academic performance of male and female students taught technology Education using simulation game in the Nigeria secondary schools.

\section{METHODOLOGY}

The research method adopted in this research was pretest, treatment control, Posttest design. Intact classes were used for the study. The experimental group was taught education technology lesson using simulation game strategy while the control group was taught education technology lesion using simulation game strategy while the control group was taught without simulation give strategy. The study was calculated in Government Technical College Chanchaga, Minna, Niger state. Two arms (, JSS1 JSS2B, JSS2C, class) where randomly selected for the study. JSS2B was used as the experiment group while JSS2C was the control group they were 30 students in each class. The instrument use for data collection was designed by the researcher. The instrument was a 20 item objective designed to represent the real life activities of learning. This was used for pre-test and post-test. Question where drained from the two topic taught in Technology education. These topics were taught for these weeks.

The scares realized were correlated using Kueler Richardson correlation analysis which yielded a coefficient of 0.76 mean scores and T-test were used for analysis by data collection. Mean scores were used to answer the research questions, while T-test were used to test the hypotheses findings. 


\section{Research Question One}

How can simulation give enhance teaching and leaning of technology education in the Nigeria secondary school?

Table 1

\begin{tabular}{lll}
\hline Group & Number of students & Mean scores \\
\hline Experiments control & 30 & 17.1 \\
Control experiments & 30 & 15.1
\end{tabular}

The above table revealed that students taught using simulation game had mean scores of 17.1 while those taught without simulation game had a mean scores of 15.1 their indicated that these taught using simulation game performed significantly better their those taught without simulation game.

\section{Research Question Two}

How can simulation game enhance teaching technology education of male and female in the Nigeria secondary schools?

Table 2: Mean scores of male and female students

\begin{tabular}{lll}
\hline Gender & NO of students & Mean scores \\
\hline Male & 15 & 17.7 \\
Female & 15 & 16.5 \\
\hline
\end{tabular}

From the table above, the mean scores of the male 17.7 was higher than that of females with 16.5 meaning that male performed better than the females although different in the performance was not significant.

\section{Hypothesis one (HO1)}

There is no significant difference on the academic performance of students taught technology education using simulation game in the teaching and learning process.

Table 3

\begin{tabular}{llllll}
\hline Group & No of students & Mean scores & Df & Probability level & Std deviation \\
\hline Experiment & 30 & 17.1 & 29 & 0.05 & 1.17 \\
Control & 30 & 15.1 & 29 & 0.05 & 1.87
\end{tabular}

The above table revealed that T- calculated which is 7.38 is more that T-critical of 2.66, meaning better experiment group performed better than the control group. Based on their, the null hypothesis was rejected as it revealed that there is a significant difference on the academic performance of the experimental group and the control group. Their difference can be attributed to the use or simulation game in the teaching and learning process since all other conflictions were same for both groups.

\section{Hypothesis Two (H02)}

There is no significant difference in the academic performance of male and female students taught technology education using simulation game in the Nigeria secondary schools. 
Tables 4

\begin{tabular}{|c|c|c|c|c|c|c|c|c|c|}
\hline Gender & $\begin{array}{l}\text { No } \\
\text { student }\end{array}$ & of & $\begin{array}{l}\text { Mean } \\
\text { scores X }\end{array}$ & $\begin{array}{l}\text { Standard } \\
\text { deviation }\end{array}$ & $\mathrm{df}$ & Probability level & t-cal & t-critical & Decision \\
\hline Male & 15 & & 17.7 & 0.88 & 14 & 0.05 & 2.39 & 2.763 & \\
\hline Female & 15 & & 15.9 & 2.95 & 14 & 0.05 & 2.39 & 2.763 & Accept \\
\hline
\end{tabular}

The above table revealed that t-calculated is 2.3 .9 which is less that the hypothesis 4 was accepted, therefore contained that there is no significant difference in the academic performance of male and female students taught technology education using simulation game in the Nigeria Secondary Schools.

The result shows no difference in the use of simulation game in teaching and learning among male and female students. Meaning that simulation game strategy is gender friendly.

\section{DISCUSSION}

The result of this study revealed that the use of simulation game in teaching and learning technology education enhanced student's performance. The prove was from the scores of the experimental and control groups respectively where the experimental group performed significant better (17.7 and 15.9). The finding is in time with Jimmy (2014) who stated that simulation game is an appropriate method of teaching and learning in both primary and secondary schools especially in the Nigeria Schools where culture is still in the higher rank.

The study also revealed that there is no significant difference on the academic performances of male and female students (boys and girls) taught using simulation game in technology education. Both sex performed uniformly. This result confirmed the finding as Brown (2012) which revealed that gender has no influence when exposed to the use of educative game in teaching and learning of any subject in both primary and secondary schools.

\section{CONCLUSION}

Simulation again is a special category of real things or a simplified operational model of a real situation that produces with various participation in the varieties of role and event. Simulation game which means the initiative representation of the functioning or workability of one system or process of a system over time promotes effective teaching and learning among different levels of learners.

\section{RECOMMENDATION}

Based on the findings from this research, it was recommended that the following should be considered by the teachers, students, school administrators and government in general.

\section{Reference}

Abret, C. (2008). Programme games and the learning of problem-solving skills. Journal of Education Research, vol. 3 PP. 10-31

Boocock, J.C. (2000). Simulation game and control beliefs, John Hopkins University Press ltd London

Brown, C. (2012). Developments in simulation of international Relation in Higher School Teaching. Journal of Educational Research Review, vol. 5 pp 210-220

Jummy, F. (2014). Simulation: New Direction in Teacher Preparation. Michigan State University Press

Ore, C.C. (2000). Instructional simulation and game: A Research Development and dissemination activity in

Teaching and learning Process. Journal of curriculum studies 3(5), 23-32 
Raymound, P.C. (2010). Simulation in teacher Education Programmed instruction, vol. 2 pp, 21-32

Robert, J.C. (2010). Simulation and Society: An Exploration of Scientific Gaming. Vol. 2, 18-29

Wilson, J.C. (2009). The simulation of cultural Differences. The Journal of Communication, vol. 6, pp 21-30 